\title{
STIRRING EFFECT ON ZEOLITES SYNTHESIS WITH DIFFERENT SI/AL MOLAR RATIOS USING 1-BUTYL-3-METHYLIMIDAZOLIUM CHLORIDE AS STRUCTURE-DIRECT AGENT
}

\author{
Efeito da agitação na síntese de zeólitas com diferentes razões molares \\ Si/Al utilizando cloreto de 1-butil-3-metilimidazólio como direcionador de \\ estrutura
}

\begin{abstract}
Marcelo L. Mignoni ${ }^{1}$; Victor de Aguiar Pedott ${ }^{1}$; Catia S. Z. Battiston ${ }^{2}$; Carolina E. Demaman Oro ${ }^{1}$, Michele O. de Souza ${ }^{3}$; Sibele B.C. Pergher ${ }^{4}$; Rogério Marcos Dallago'; Roberto F. de Souza ${ }^{3 \#}$; Katia Bernardo-Gusmão ${ }^{3}$
\end{abstract}

\begin{abstract}
${ }^{1}$ Departamento de Química, Universidade Regional Integrada do Alto Uruguai e das Missões, Erechim, RS. E-mail address: mignoni@uricer.edu.br

${ }^{2}$ Instituto Federal de Educação, Ciência e Tecnologia do Rio Grande do Sul - Campus Erechim, RS.

${ }^{3}$ Instituto de Química, Universidade Federal do Rio Grande do Sul, Porto Alegre, RS.

${ }^{4}$ LABPEMOL, Instituto de Química, Universidade Federal do Rio Grande do Norte, Natal.

"In memorian
\end{abstract}

Data do recebimento: 02/04/2020 - Data do aceite: 01/06/2020

Resumo: Diferentes tipos de zeólitas podem ser sintetizadas alterando variáveis no processo de síntese. O presente trabalho estuda o efeito de agitação na síntese de zeólitas com diferentes proporções molares de $\mathrm{Si} / \mathrm{Al}(1,8,20$, 50 e 120), usando o líquido iônico cloreto de 1-butil-3-metilimidazólio (BMI. $\mathrm{Cl}$ ) como agente direcionador da estrutura. Os resultados obtidos mostraram a alta eficiência do líquido iônico BMI. Cl como agente direcionador, para a cristalização de zeólitas tipo A, ZSM-5, Beta e ZSM-35. O efeito de agitação nos parâmetros morfológicos e composicionais aparentam ser significativos. Sendo assim, diagramas ternários de composição foram plotados para as condições estáticas e de agitação, evidenciando a influência da agitação na composição e morfologia dos materiais gerados. Nos diagramas ternários foi possível verificar as condições de obtenção das zeólitas ZSM-5 e ZSM35 puras, bem como as diferentes morfologias encontradas para as mesmas 
regiões, quando as zeólitas foram sintetizados em condições estáticas e de agitação. Observa-se, também, que as zeólitas ZSM-35 e Beta mostram uma quantidade maior de $\mathrm{Al}_{2} \mathrm{O}_{3}$ (4\% em mol e 1,6\% em mol) apenas quando a reação é realizada sob condições de agitação.

Palavras-chave: Materiais microporosos. Síntese. Morfologia. Zeólita.

\begin{abstract}
Different types of zeolites could be synthesized changing the variables in the synthesis process. This paper studies the stirring effect on zeolites synthesis at different $\mathrm{Si} / \mathrm{Al}$ molar ratios $(1,8,20,50$ and 120) using the ionic liquid 1-butyl-3-methylimidazolium chloride (BMI.Cl) as structure-direct agent. The results suggest that the ionic liquid BMI.Cl would be a highly effective directing agent for the crystallization of zeolites type A, ZSM-5, Beta and ZSM-35. The stirring effect on compositional and morphological parameters seems to be significant. Therefore, ternary composition diagrams were plotted for the static and stirring conditions, showing the influence of stirring on the composition and morphology of the generated materials. It was possible to verify, in the ternary diagrams, the conditions for obtaining the pure ZSM-5 and ZSM-35 zeolites, as well as the different morphologies found for the same regions, when the zeolites were synthesized under static and stirring conditions. It is also observed that the zeolites ZSM-35 and Beta show a greater amount of A12O3 (4 mol\% and $1.6 \mathrm{~mol} \%$ ) only when the reaction is carried out under stirring conditions.
\end{abstract}

Keywords: Microporous materials. Synthesis. Morphology. Zeolite.

\section{Introduction}

Zeolites are microporous materials with framework characterized by TO4 $(\mathrm{T}=\mathrm{Si}$, Al) tetrahedral three-dimensional structure with interconnected cavities and channels, which leads to high specific surface areas (MOLINER; MARTÍNEZ; CORMA, 2015). The amount of $\mathrm{Al}$ within the framework can vary over a wide range of $\mathrm{Si} / \mathrm{Al}$ relations, which could lead to different zeolites frameworks (INGLEZAKIS; ZORPAS, 2012).

Zeolites are usually synthesized under hydrothermal conditions, where the reaction variables including time, temperature, gel composition, stirring and reactant source influence the framework formation (CORMA; MOLINER; ROMA, 2019). Another factor that could influence on framework is the use of Structure Directing Agents (SDA's), composed by organic and inorganic cations, causing a competition between zeolitic phases (DI RENZO, 1998; HAMILTON et al., 1993; HINCAPIE et al., 2004; LIMA, 2014; MINTOVA et al., 2007; VALTCHEV et al., 1995). Therefore, the gel formation is a crucial parameter in the nucleation process, where a large number of cores are produced, due to high degree of supersaturation caused by the ionic species, which affects the crystal size and morphology of zeolite phases (KUZIELOVÁ et al., 2020; MINTOVA et al., 2016). 
Many studies show that the composition of the starting gel used in the synthesis have a great influence on crystal size and morphology (DI RENZO, 1998; HINCAPIE et al., 2004; VALTCHEV et al., 1995; ZHUANG et al., 2018). Stirring conditions on the starting gel has been shown as a very important parameter, whose effects have been explained as consequences of changes in local concentrations, transport properties and in the "structure" of the gel (KIM; CHUNG, 2003).

Zeolite frameworks as Beta and TONtype, synthesized under hydrothermal conditions, require stirring during synthesis, where with these conditions, the gel properties as TEAOH/SiO2 molar ratio, crystallization kinetics, particle size and particle size distribution, lead to structure formation, as described in literature (DING et al., 2006).

Ionic liquids could act as SDA and solvent in zeolite synthesis, assigning great potential for its application due to its properties as green-chemistry, low vapor pressure and the possibility of imidazolium-based cations lead to many different geometries in synthesis of zeolite structures (MORRIS, 2009; VINACHES; BERNARDO-GUSMÃO; PERGHER, 2017). The association between the use of the supramolecular arrangements, well-known in the ionic liquids, induce specific crystallization of zeolitic structures (LOPES et al., 2015; SACHSE et al., 2015).

Many works involving ionic liquids acting as SDA's have been published along the years, obtaining different zeolites frameworks as, H-ZSM-5, MER-type zeolites, 10-MR zeolites and $\mathrm{NaP}$ zeolites and also for a wide range of materials (HAOUAS et al., 2014; HUANG; CHEN, 2013; LI et al., 2019, 2020; SOLL; ANTONIETTI; YUAN, 2014; ZARE et al., 2020; ZHAO et al., 2009).

Zeolites have many important industrial applications, they practically dominate the heterogeneous catalysis and are also used as adsorbents for the removal of ions, gases and etc. (QUEROL et al., 1997; SINGH; KOLAY, 2002). Mostly used as acid catalyst in petrochemical industry, zeolites have several desirable catalytic properties due to limitations from pore size, which brings a shape selectivity regarding the products. They are also used as supports for transition metals, creating unique catalytic sites, with defined and ordered structure (CORMA, 2003; SONG et al., 2004).

Therefore, for a better understanding of stirring influence on zeolite framework formation, this paper will be presented to study the effect of stirring on the synthesis of zeolites with different molar ratios $\mathrm{Si} / \mathrm{Al}$ $(1,8,20,50$ and 120) using the ionic liquid 1-butyl-3-methylimidazolium chloride as structure-direct agent.

\section{Experimental}

Zeolites were synthesized under static and stirring conditions using 1-butyl-3methylimidazolium chloride (BMI.Cl) as structure-direct agent. The ionic liquid was synthesized according to published procedure (DUPONT et al., 2002). The reactants used in this study were sodium aluminate $\left(\mathrm{Na}_{2} \mathrm{Al}_{2} \mathrm{O}_{4}\right.$, Riedel-de-Haen) as the aluminum source, $\mathrm{SiO}_{2}$ (aerosil 200, Degussa) as the silica source, the ionic liquid 1-butyl-3methylimidazolium chloride (BMI.Cl) as SDA, $\mathrm{NaOH}$ pellets (Sigma-Aldrich 97\%) and deionized water.

In order to study the crystallization of zeolites, five syntheses were performed with different molar compositions. Table I shows the percentage molar ratios used in each synthesis.

The zeolite synthesis occurred as follows: $i$ ) in a beaker, the $\mathrm{SiO}_{2}$ was dissolved in 
deionized water $(60 \mathrm{~mL})$, under 15 minutes of agitation, and then the BMI.Cl was added, obtaining solution A. ii) initially the $\mathrm{NaOH}$ was solubilized in deionized water $(60 \mathrm{~mL})$ and then the $\mathrm{Na}_{2} \mathrm{Al}_{2} \mathrm{O}_{4}$ was added, obtaining solution B. This solution was stirred for 15 minutes. iii) Finally, the solution B was added in solution A to originate the synthesis gel (solution C) which was left under agitation for further 15 minutes to total homogenization of the reactants.

Table I - Percentage molar and molar ratios used in each synthesis

\begin{tabular}{|ccccc|}
\hline Synthesis & $\mathbf{S i} / \mathbf{A l}$ & $\begin{array}{c}\mathbf{m o l} \% \\
\mathbf{S i O}_{2}\end{array}$ & $\begin{array}{c}\mathbf{m o l} \% \\
\mathbf{A l}_{\mathbf{2}} \mathbf{O}_{\mathbf{3}}\end{array}$ & $\begin{array}{c}\mathbf{m o l} \% \\
\mathbf{N a}_{\mathbf{2}} \mathbf{O}\end{array}$ \\
\hline 1 & 1 & 44.5 & 19.2 & 36.3 \\
2 & 8 & 74.0 & 4.0 & 22.0 \\
3 & 20 & 76.8 & 1.6 & 21.6 \\
4 & 50 & 89.0 & 1.0 & 10.0 \\
5 & 120 & 81.3 & 0.3 & 18.4 \\
\hline
\end{tabular}

Then, three equal volumes of the solution $\mathrm{C}$ gel were poured into $60-\mathrm{mL}$ capacity Teflon-lined stainless-steel autoclaves and maintained in an oven at $180{ }^{\circ} \mathrm{C}$ for 3,7 and 14 days, where the samples were submitted to static or stirring conditions. After the reaction time, the solids were filtered and washed with $50 \mathrm{~mL}$ of deionized water and $50 \mathrm{~mL}$ of acetone, and then dried for $5 \mathrm{~h}$ at $105{ }^{\circ} \mathrm{C}$.

The zeolitic phase of samples was characterized by X-ray diffraction (XRD) on a Siemens D500 diffractometer with $\mathrm{Cu}$ $\mathrm{K} \alpha$ radiation $(\lambda=1.54056 \AA)$. For $\mathrm{X}$-ray data collection, after calcination $\left(600^{\circ} \mathrm{C}\right)$, a sample was placed in a glass measurement cell that was quickly closed to avoid contact with moisture, then degassed at $300{ }^{\circ} \mathrm{C}$ under vacuum prior to measurements. The morphology and particle size of the products were investigated using a SSZ 550 (Shimadzu) scanning electron microscope (SEM). The specific surface areas were determined from nitrogen adsorption on Micrometrics Gemini VacPrep 061 using the BET method.

\section{Results and discussion}

Different compositions of the synthesis gel were originated by mixing $\mathrm{SiO}_{2}, \mathrm{Na}_{2} \mathrm{~A}$ $1_{2} \mathrm{O}_{4}, \mathrm{NaOH}$, and $\mathrm{BMI} . \mathrm{Cl}$ in water, leading to different zeolitic structures, which were also influenced by the reaction parameters like composition, agitation and temperature

\section{Synthesis under static condition}

Figure 1 shows the XRD patterns of the materials obtained with different silicon/aluminum molar ratios under static conditions

Figure 1 - X-ray diffractograms of materials obtained in 3 days of synthesis using $\mathrm{BMI}$.Cl as template at different ratios under static conditions

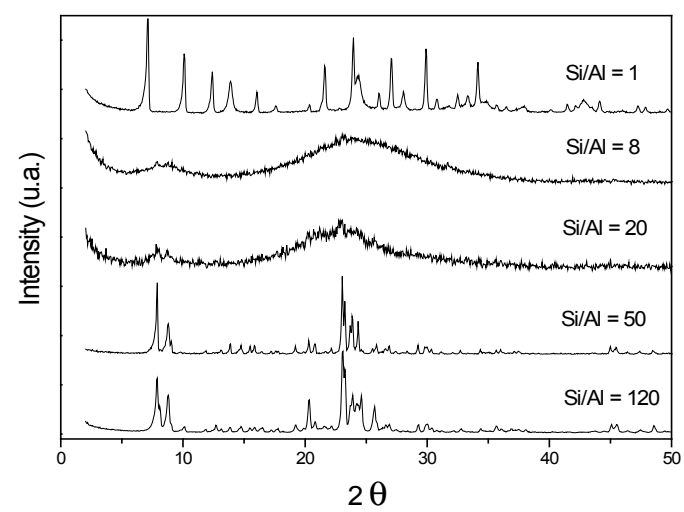

The synthesis of zeolites, under static conditions, were conducted at three different times, where the results obtained from 3, 7 and 14 days of synthesis are the same, showing that the reaction time have no influence in the structure formation for the tested $\mathrm{Si}$ / Al molar relations. The diffractogram for $\mathrm{Si} / \mathrm{Al}=1$ show very characteristic $2 \theta$ lines 
of zeolite A at $7.13^{\circ}, 10.22^{\circ}, 12.51^{\circ}, 16.19^{\circ}$, $21.68^{\circ}, 23.94^{\circ}, 27.17^{\circ}, 30.02^{\circ}, 34.08^{\circ}$ and $42.7^{\circ}$ (TREACY; HIGGINS, 2001). However, we also observe the appearance of peaks in $14.04^{\circ}$ and $24.29^{\circ}$, characteristic of sodalite zeolite. In molar ratios of 8 and 20 no structure are formed, the obtained material presents an amorphous morphology.

From a molar ratio $\mathrm{Si} / \mathrm{Al}=50$ and $\mathrm{Si} / \mathrm{Al}=$ 120 is possible to verify the presence of peaks indicating the obtainment of a crystalline material showing very characteristic lines of a ZSM-5 framework at $7.97^{\circ}, 8.82^{\circ}, 23.10^{\circ}$, $23.35^{\circ}, 23.86^{\circ}$, and $24.35^{\circ}$ (VALTCHEV et al., 1995). However, the $\mathrm{Si} / \mathrm{Al}=120$ ration have a mixture of phases like demonstrated by the peaks in $20.3^{\circ}$ and $26.0^{\circ}$ characteristic of quartz phase.

In order to clearly demonstrate the effect of individual component on the crystalliza- tion of zeolites and the interaction between components, under static conditions, a ternary compositional diagram for $\mathrm{SiO}_{2}, \mathrm{Al}_{2} \mathrm{O}_{3}$ and $\mathrm{Na}_{2} \mathrm{O}$ was drawn in Figure 2 at constant BMI.Cl, $\mathrm{NaOH}$ and $\mathrm{H}_{2} \mathrm{O}$ contents.

As can be seen in Figure 2, there are two compositional zones in which zeolite ZSM-5 are formed, pure or in a mixture of phases. It is interesting to notice that the pure ZSM-5 zeolite is more likely formed with a less $\mathrm{Al}_{2} \mathrm{O}_{3}$ content, approximately $2 \mathrm{~mol} \%$. However, for greater contents of $\mathrm{Al}_{2} \mathrm{O}_{3}$, there is the presence of quartz as an impurity phase as demonstrated in Figure 1. A closer look at microspheres in Figure 2 (d), for pure zeolite ZSM-5, shows agglomerates of hexagonal prisms with dimensions of approximately $30 \mu \mathrm{m}$ forming these spheres. Therefore, it is concluded that pure zeolite ZSM-5 is likely formed in the compositional zone of $89 \mathrm{~mol} \%$

Figure 2 - Ternary diagram of the gel composition of the synthesis of zeolite without agitation, with different molar ratios $\mathrm{Si} /$ Al: (a) 1, (b) 8, (c) 20, (d) 50 and (e) 120

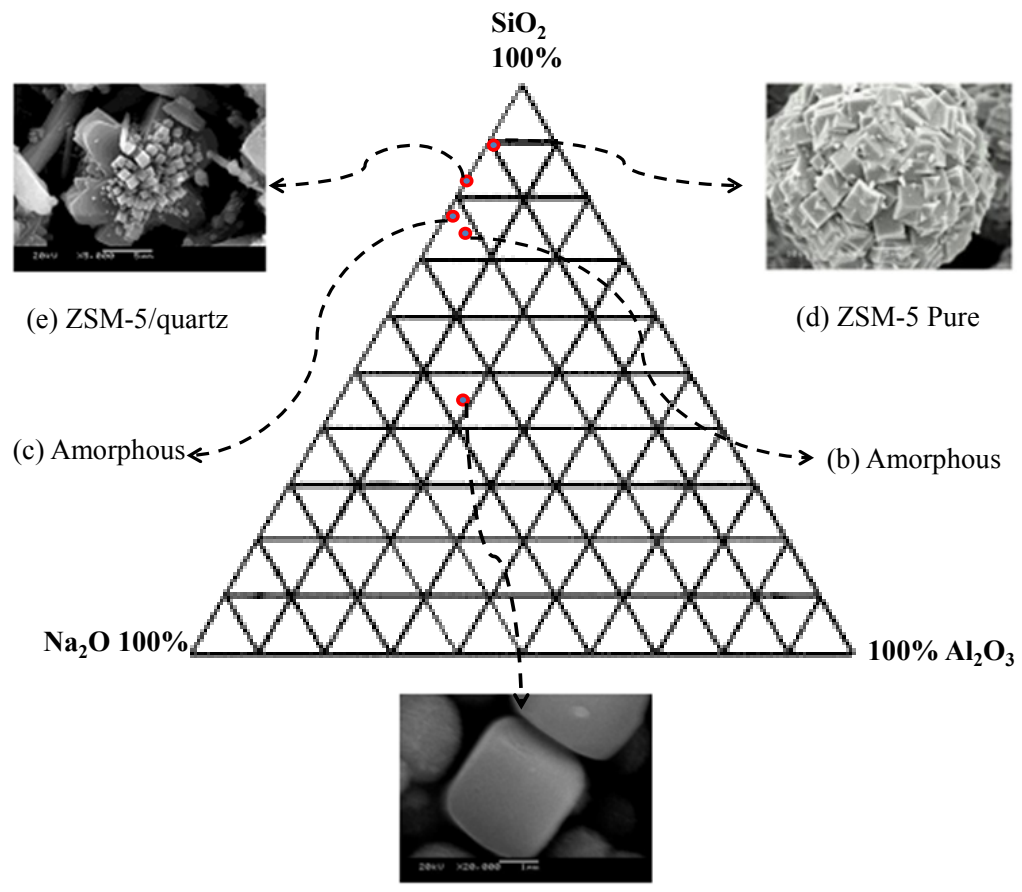

(a) Zeolite A/Sodalite 
$\mathrm{SiO}_{2}, 1 \mathrm{~mol} \% \mathrm{Al}_{2} \mathrm{O}_{3}$ and $10.0 \mathrm{~mol} \% \mathrm{Na}_{2} \mathrm{O}$.

For samples (b) and (c) with molar $\mathrm{Si} / \mathrm{Al}$ ratios of 8 and 20, respectively, an amorphous morphology was shown, as verified by XRD (Fig. 1), however, for the (a) sample, it is possible to notice the formation of two phase zeolite A/sodalite, characteristic of small molar Si/Al ratio (JANOS B.NAGY, PIERRE BODART, I. HANNUS, 1998).

\section{Synthesis under stirring conditions}

The XRD diffractograms of the materials synthesized with different molar ratios under stirring conditions are shown in Figure 3.

Figure 3. X-ray diffractograms of materials obtained in 3 days of synthesis using BMI.Cl as directing agent at different ratios with stirring

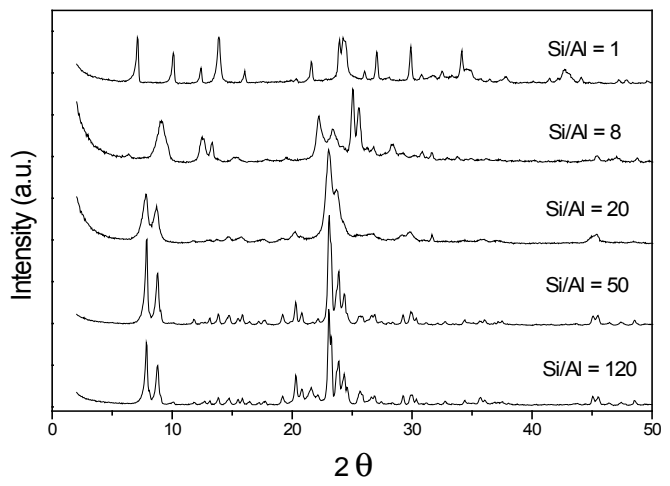

The X-ray diffractograms obtained for stirring conditions shows similar results for relation $\mathrm{Si} / \mathrm{Al}=1$, to those obtained under static conditions, where it causes the appearance of peaks characteristic of zeolite A, along with peaks in $14.04^{\circ}$ and $24.29^{\circ}$ of zeolite sodalite which appears with greater intensity when synthesized in static conditions. For relation $\mathrm{Si} / \mathrm{Al}=8$ is possible to observe the influence of stirring in the synthesis process. In these case, we observe the formation of peaks characteristic of ZSM-35 framework at $2 \theta$ values of $9.23^{\circ}, 12.68^{\circ}, 13.38^{\circ}, 22.21^{\circ}$, $23.45^{\circ}, 25.04^{\circ}, 25.52^{\circ}$ and $28.31^{\circ}$, showing that stirring has a positive influence on the formation of ZSM-35 structures (GUO et al., 2017).

Analyzing the molar relationship $\mathrm{Si} / \mathrm{Al}=$ 20 , it is possible to observe the formation of a crystalline phase, with peaks at $7.7^{\circ}, 8.8^{\circ}$ and $23.0^{\circ}$, characteristic of $\beta$-zeolites (GUO et al., 2017), where in the synthesis process under static conditions, for the same relation, no structure was obtained. When the $\mathrm{Si} / \mathrm{Al}$ ratio increased to 50 , well-defined peaks are observed, indicating the presence of a crystalline phase, characteristic $2 \theta$ lines of a ZSM-5 framework at $7.97^{\circ}, 8.82^{\circ}, 23.10^{\circ}$, $23.35^{\circ}, 23.86^{\circ}$, and $24.35^{\circ}$ (GUO et al., 2017) where this result can also be observed in the synthesis without agitation showing little influence of stirring for these relations. Results of synthesis with molar ratios $\mathrm{Si} / \mathrm{Al}$ of 20 and 50 were previously reported by our research group (MIGNONI et al., 2010).

When the molar ratio increases to $\mathrm{Si} / \mathrm{Al}=$ 120 in the reaction under stirring conditions, the pure phase zeolite ZSM-5 is formed. This result was not observed in the synthesis without agitation, where there was the formation of ZSM-5 phase with impurities of quartz, concluding that stirring disfavors the formation of quartz.

For a better visualization of the obtained results under stirring conditions, a ternary compositional diagram for $\mathrm{SiO}_{2}, \mathrm{Al}_{2} \mathrm{O}_{3}$ and $\mathrm{Na}_{2} \mathrm{O}$ is shown in Fig. 4 at constant BMI.Cl, $\mathrm{NaOH}$ and $\mathrm{H}_{2} \mathrm{O}$ contents.

Under stirring conditions a molar composition of $74.0 \mathrm{~mol} \% \mathrm{SiO}_{2}, 4.00 \mathrm{~mol} \% \mathrm{Al}_{2} \mathrm{O}_{3}$ and $22.0 \mathrm{~mol} \% \mathrm{Na}_{2} \mathrm{O}$, leads to the obtaining of pure beta zeolite, a fact not observed in the synthesis under static conditions. In addition, the utilization of $76.8 \mathrm{~mol}^{\%} \mathrm{SiO}_{2}, 1.6 \mathrm{~mol} \%$ $\mathrm{Al}_{2} \mathrm{O}_{3}$ and $21.6 \mathrm{~mol} \% \mathrm{Na}_{2} \mathrm{O}$ under stirring conditions directs to obtaining of pure zeolite 
Figure 4 - Ternary diagram of the gel composition of the synthesis of zeolite with stirring, with different molar ratios $\mathrm{Si} / \mathrm{Al}$ : (a) 1 , (b) 8 , (c) 20, (d) 50 and (e) 120

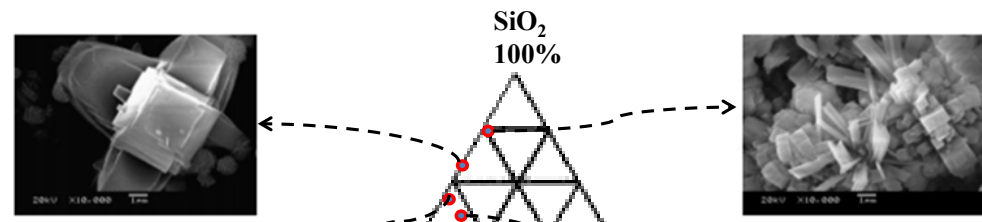

(e) ZSM-5 Pure

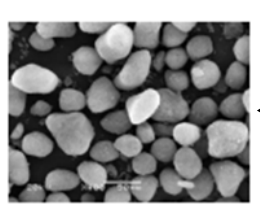

(c) ZSM-35 Pure

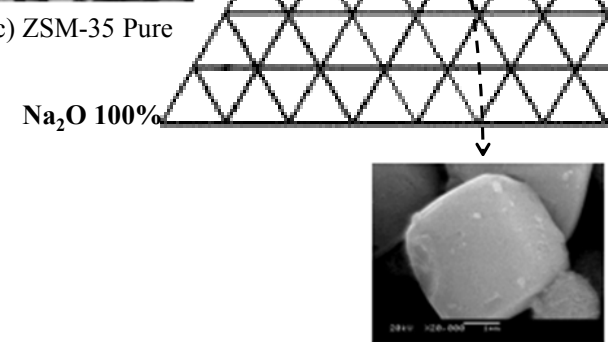

(a) Zeolite A/Sodalite (d) ZSM-5 Pure

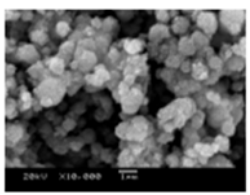

(b) Beta Pure

\section{ZSM-35 phase.}

Comparing the ternary compositional diagrams, it is possible to notice the influence of static or stirring conditions, under stirring conditions ZSM-35, beta, Zeolite A/Sodalite and ZSM-5 structures were obtained and under static conditions only zeolite A/sodalita, pure ZSM-5 and ZSM-5/quartz zeolites structures were obtained, showing the positive influence of stirring for the investigated $\mathrm{Si} / \mathrm{Al}$ relations. In addition, it is clearly seen that the obtaining of pure ZSM-5 structures is a compositional zone with molar ratio between $\mathrm{Si} / \mathrm{Al}=50$ and 120 under stirring or static conditions.

The morphology of the obtained materials depends on the synthesis system used. Under static or stirring conditions, the main influence on shape of crystals seems to be given by density of the synthesis gel (BODART et al., 1984). When the gel is denser over the elongated shape, the formation of hexagonal prisms is favored, where static conditions favors the appearance of hexagonal prisms due to higher densities of the synthesis gel.

\section{Surface properties}

For materials that showed crystallinities, specific areas of the synthesized materials were obtained by textural analysis of $\mathrm{N}_{2}$ adsorption/desorption, these results are shown in Table II.

Observing the Table II it is possible to verify that the crystalline materials obtained under static conditions, the highest surface area was obtained for the zeolite with a $\mathrm{Si} /$ $\mathrm{Al}$ ratio 50 . For the zeolite obtained with $\mathrm{Si} /$ $\mathrm{Al}=1$ a very low area are obtained, explained by the no accessibility of the molecule $\mathrm{N}_{2}$ to the interior of the zeolite due to small 
Table II - Specific areas of the synthesized materials were obtained by textural analysis of $\mathrm{N}_{2}$ adsorption and desorption

\begin{tabular}{ccccc}
\hline Ratios Si/Al & $\begin{array}{c}\text { Surface area } \\
\text { BET }\left(\mathbf{m}^{2} \cdot \mathbf{g}^{-1}\right)\end{array}$ & $\begin{array}{c}\text { Microporous } \\
\text { volume }\left(\mathbf{c m}^{\mathbf{3}} \cdot \mathbf{g}^{-1}\right)\end{array}$ & $\begin{array}{c}\text { Mesoporous } \\
\text { volume }\left(\mathbf{c m}^{\mathbf{3}} \cdot \mathbf{g}^{-1}\right)\end{array}$ \\
\hline \multirow{5}{*}{ Without stirring } & 1 & 4 & - & - \\
& 8 & - & - & - \\
& 20 & - & - & - \\
& 50 & 384 & 0.10 & - \\
\hline \multirow{3}{*}{ With stirring } & 120 & 253 & 0.18 & - \\
& 1 & 3 & - & - \\
& 20 & 342 & 0.11 & - \\
& 50 & 312 & 0.13 & - \\
\hline
\end{tabular}

values of openings rings cavities. This fact is a consequence of the presence of $\mathrm{Na}^{+}$cations, causing small opening of the ring cavities, smaller than the size of $\mathrm{N}_{2}$ molecule, thus, it was not possible to determine the pore size (RIGO et al., 2009; XU et al., 2007).

Under stirring conditions, it is observed that all obtained materials are crystalline and showed high surface areas, except for the $\mathrm{Si}$ / $\mathrm{Al}=1$, fact also observed in the synthesis without stirring. As can be seen in table 2, at $\mathrm{Si} / \mathrm{Al}=20$ relations, under stirring conditions, occurs the appearance of mesopores leading to high values of surface area for these material.

\section{Conclusions}

Several conclusions have been drawn through this study. The results suggest that ionic liquid BMI.Cl would be highly effective directing agent for the crystallization of zeolites type A, ZSM-5, Beta and ZSM-35. The effect of stirring on the composition and morphology seems to be significant. The ternary compositional diagram shows that the compositional zone for pure zeolite ZSM-5 under static and stirring conditions has been shifted to lower $\mathrm{Al}_{2} \mathrm{O}_{3}$ content of less than 2.0 $\mathrm{mol} \%$, but it is possible to observe the difference between the morphology when zeolites synthesized in static or stirring conditions. Also observed, the zeolite ZSM-35 and Beta, showing a higher amount of $\mathrm{Al}_{2} \mathrm{O}_{3}(4 \mathrm{~mol} \%$ and $1.6 \mathrm{~mol} \%$ ), are obtained only when the reaction is carried out under agitation.

Acknowledgments: This study was financed part by the Coordenação de Aperfeiçoamento de Pessoal de Nível Superior - Brasil (CAPES) - Finance Code 001. The authors would like to thank Conselho Nacional de Desenvolvimento Científico e Tecnológico (CNPq) and the Research Support Foundation of Rio Grande do Sul (FAPERGS).

Conflict of interest: Authors claim no con- 
flict of interest.

\section{REFERENCES}

BODART, P. et al. Study of Mordenite Crystallization III: Factors Governing Mordenite Synthesis. [s.l: s.n.]. v. 18

CORMA, A. State of the art and future challenges of zeolites as catalysts. Journal of Catalysis, v. 216, n. 1-2, p. 298-312, 2003.

CORMA, A.; MOLINER, M.; ROMA, Y. Machine Learning Applied to Zeolite Synthesis : The Missing Link for Realizing High-Throughput Discovery. Accounts of Chemical Research, v. 52, n. 10, p. 2971-2980, 2019.

DI RENZO, F. Zeolites as tailor-made catalysts: Control of the crystal size. Catalysis Today, v. 41, n. 1-3, p. 37-40, 1998.

DING, L. et al. Effect of agitation on the synthesis of zeolite beta and its synthesis mechanism in absence of alkali cations. Microporous and Mesoporous Materials, v. 94, n. 1-3, p. 1-8, 2006.

DUPONT, J. et al. Preparation of 1-Butyl-3-Methyl Imidazolium-Based Room Temperature Ionic Liquids. Organic Syntheses, v. 79, n. September, p. 236, 2002.

GUO, P. et al. Database mining of zeolite structures. Crystal Growth and Design, v. 17, n. 12, p. 6821-6835, 2017.

HAMILTON, K. E. et al. The effects of the silica source on the crystallization of zeolite NaX. Zeolites, v. 13, n. 8, p. 645-653, 1993.

HAOUAS, M. et al. Silicate ionic liquid synthesis of zeolite merlinoite: Crystal size control from crystalline nanoaggregates to micron-sized single-crystals. Microporous and Mesoporous Materials, v. 198, p. 35-44, 2014.

HINCAPIE, B. O. et al. Synthesis of mordenite nanocrystals. Microporous and Mesoporous Materials, v. 67, n. 1, p. 19-26, 2004.

HUANG, S. J.; CHEN, P. Y. Fabrication of macroporous Pt and PtAu electrodes for electrochemical application through galvanic replacement at macroporous $\mathrm{Cu}$ electrode electrodeposited at polystyrene template from room temperature ionic liquid. Electrochimica Acta, v. 89, p. 180-190, 2013.

INGLEZAKIS, V. J.; ZORPAS, ANTONIS A. Handbook of Naturla zeolites. 1. ed. Dubai U.A.E.: Bentham Science Publishers, 2012.

JANOS B.NAGY, PIERRE BODART, I. HANNUS, I. K. Synthesis, characterization and use of zeolitic microporous materials. 1. ed. Szeged (Hungria): DecaGen Ltd., 1998.

KIM, D. J.; CHUNG, H. S. Synthesis and characterization of ZSM-5 zeolite from serpentine. Applied Clay Science, v. 24, n. 1-2, p. 69-77, 2003.

KUZIELOVÁ, E. et al. Influence of hydrothermal treatment parameters on the phase composition of zeolites. Journal of Thermal Analysis and Calorimetry, v. 3, n. 0123456789, 2020.

LI, P. et al. Porous Liquid Zeolites : Hydrogen Bonding-Stabilized H- Porous Liquid Zeolites : Hydrogen Bonding-Stabilized H-ZSM-5 in Branched Ionic Liquids †. Nanoscale, v. 11, n. 4, p. 1515-1519, 2019.

LI, X. et al. Microporous and Mesoporous Materials Ionic liquid-templated synthesis of 10-MR zeolites and its origin disclosure. Microporous and Mesoporous Materials, v. 305, n. 6, p. 1-7, 2020. 
LIMA, R. C. Universidade Federal Do Rio Grande Do Norte Universidade Federal Do Rio Grande Do Norte. [s.l.] Universidade Federal do Rio Grande do Norte como, 2014.

LOPES, C. W. et al. TiO2-TON zeolite synthesis using an ionic liquid as a structure-directing agent. Microporous and Mesoporous Materials, v. 213, p. 78-84, 2015.

MIGNONI, M. L. et al. Nickel oligomerization catalysts heterogenized on zeolites obtained using ionic liquids as templates. Applied Catalysis A: General, v. 374, n. 1-2, p. 26-30, 2010.

MINTOVA, S. et al. Crystallization kinetics of Zeolite SZM-5. v. 25, n. 3, p. 210-215, 2007. MOLINER, M.; MARTÍNEZ, C.; CORMA, A. Multipore zeolites: Synthesis and catalytic applications. Angewandte Chemie - International Edition, v. 54, n. 12, p. 3560-3579, 2015.

MORRIS, R. E. Ionothermal synthesis - Ionic liquids as functional solvents in the preparation of crystalline materials. Chemical Communications, n. 21, p. 2990-2998, 2009.

QINHUA, X.; AIZHEN, Y. Hydrothermal synthesis and crystallization of zeolites. Progress in Crystal Growth and Characterization of Materials, v. 21, n. 1-4, p. 29-70, 1991.

QUEROL, X. et al. Synthesis of Na-zeolites from fly ash. Fuel, v. 76, n. 8, p. 793-799, 1997.

RIGO, R. T. et al. A new procedure for a zeolite synthesis from natural clays. Química Nova, v. 32, n. 1, p. 21-25, 2009.

SACHSE, A. et al. Mesoporous y zeolite through ionic liquid based surfactant templating.

Microporous and Mesoporous Materials, v. 217, p. 81-86, 2015.

SINGH, D. N.; KOLAY, P. K. Simulation of ash-water interaction and its influence on ash characteristics. Progress in Energy and Combustion Science, v. 28, n. 3, p. 267-299, 2002.

SOLL, S.; ANTONIETTI, M.; YUAN, J. Poly(ionic liquid) nanoparticles as novel colloidal template for silica nanocasting. Polymer, v. 55, n. 16, p. 3415-3422, 2014.

SONG, W. et al. Synthesis, Characterization , and Adsorption Properties of Nanocrystalline ZSM-5. Langmuir, v. 20, n. 18, p. 8301-8306, 2004.

TREACY, M. M.; HIGGINS, J. B. Collection of Simulated XRD Powder Patterns for Zeolites. 4. ed. [s.1.] Elsevier Ltd., 2001.

VALTCHEV, V. et al. Tribochemical activation of seeds for rapid crystallization of zeolite Y.

Zeolites, v. 15, n. 3, p. 193-197, 1995.

VINACHES, P.; BERNARDO-GUSMÃO, K.; PERGHER, S. B. C. An introduction to zeolite synthesis using imidazolium-based cations as organic structure-directing agents. Molecules, v. 22, n. 8, 2017.

ZARE, A. et al. Synthesis and characterization of NaP zeolite nanocrystals using [C $12 \mathrm{mim}][\mathrm{Cl}$ ] ionic liquid. Chemical Papers, v. 74, n. 7, p. 2163-2174, 2020.

ZHAO, M. et al. Fabrication of silica nanoparticles and hollow spheres using ionic liquid microemulsion droplets as templates. Colloids and Surfaces A: Physicochemical and Engineering Aspects, v. 346, n. 1-3, p. 229-236, 2009.

ZHUANG, G. LIN et al. Trace phosphorus-doping significantly improving S-content of binarydoped mesoporous carbon network with enhancing electrochemical performance. Microporous and Mesoporous Materials, v. 256, p. 75-83, 2018. 